\title{
High aluminum concentration and initial establishment of Handroanthus impetiginosus: clues about an Al non-resistant species in Brazilian Cerrado
}

\author{
Ane Marcela das Chagas Mendonça ${ }^{1} \cdot$ Jean Marcel Sousa Lira $^{2} \cdot$ \\ Ana Luiza de Oliveira Vilela ${ }^{3}$. Daniel Amorim Vieira ${ }^{1}$ Nayara Cristina de Melo ${ }^{4}$. \\ João Paulo Rodrigues Alves Delfino Barbosa ${ }^{1}$
}

Received: 11 March 2019 / Accepted: 27 May 2019 / Published online: 25 September 2019

(C) The Author(s) 2019

\begin{abstract}
Cerrado soils are acidic and nutrient-poor, with high content of solubilized $\mathrm{Al}^{3+}$. Plants growing in these conditions may display adaptations to cope with high aluminum concentrations especially during early developmental stages. We investigated leaf nutritional status, and photosynthetic and growth characteristics during the initial establishment of Handroanthus impetiginosus (Mart. Ex Dc.) Mattos, a secondary tree species distributed in the Brazilian Cerrado. Our goal was to understand leaf-level traits related to different aluminum concentrations. H. impetiginosus plants were cultivated in four different aluminum sulfate concentrations: $0,1,2$, and $4 \mathrm{mM} \mathrm{Al}$, for 40 days. We performed analyses of growth, leaf gas exchange, chloroplast pigment content, and leaf mineral nutrients. We observed a linear
\end{abstract}

Project funding: This study is supported by Finance (Code 001) of Coordination of Superior Level Staff Improvement (CAPES) and the National Council for Scientific and Technological Development (CNPq) in Brazil.

The online version is available at http://www.springerlink.com

Corresponding editor: Zhu Hong.

João Paulo Rodrigues Alves Delfino Barbosa jp.barbosa@dbi.ufla.br

1 Programa de Pós-Graduação em Fisiologia Vegetal, Departamento de Biologia, Universidade Federal de Lavras, Lavras, MG 37200-000, Brazil

2 Programa de Pós-Graduação em Ciências Ambientais, Instituto de Ciências Exatas, Universidade Federal de Alfenas, Alfenas, MG 37130-001, Brazil

3 Programa de Pós-Graduação em Fitotecnia, Departamento de Agricultura, Universidade Federal de Lavras, Lavras, MG 37200-000, Brazil

4 Instituto Federal de Educação Ciência e Tecnologia do Pará, Belém, PA 66093-020, Brazil increase of $\mathrm{Al}$ leaf content as a function of $\mathrm{Al}$ concentration in the nutrient solution. Plants grown in $1 \mathrm{mM} \mathrm{Al}$ showed a remarkable increase of $\mathrm{K}$ leaf content, net photosynthesis, stomatal conductance, and transpiration, while in $4 \mathrm{mM} \mathrm{Al}$ there were reductions of $\mathrm{N}, \mathrm{P}$, and $\mathrm{K}$ contents, gas exchange characteristics, and height. H. impetiginosus did not have mechanisms of avoidance, compartmentalization, or resistance to high $\mathrm{Al}$ concentrations. Indeed, this species showed a hormetic response, with low $\mathrm{Al}$ concentrations stimulating and high $\mathrm{Al}$ concentrations inhibiting plant responses.

Keywords Hormesis - Low Al concentration · Al toxicity $\cdot$ Cerrado species $\cdot$ Carbon assimilation

\section{Introduction}

Handroanthus impetiginosus (Mart. Ex Dc.) Mattos., popularly known as ipê roxo, is a secondary tree species distributed in Cerradão and Cerrado strictu sensu landscapes (Scolforo 2008; Salomão and Camilo 2016). It stands out for the aesthetic appeal of its flowers and it is one of the symbols of the Brazilian Cerrado (Lorenzi 2008). This vegetation domain is well known to grow over acid, dystrophic, and nutrient-poor soils (Haridasan 2008; Miatto et al. 2016).

Cerrado soils are acidic and nutrient-poor, with high content of solubilized $\mathrm{Al}^{3+}$. Under low $\mathrm{pH}$ conditions, aluminum (Al) is solubilized to $\mathrm{Al}^{3+}$ and its high content may turn toxic for plants (Fageria 2001; Siqueira Neto et al. 2009; Brunner and Sperisen 2013; Bojórquez-Quintal et al. 2017). Thus, it is expected that plants growing in the acidic conditions of the Cerrado soils will have developed physiological and morphological adaptations to this harsh environment. Aluminum can have either beneficial or toxic effects, depending on a diverse range of factors, including plant species, 
$\mathrm{Al}$ concentration, and time of exposure (Bojórquez-Quintal et al. 2017). The effects of low and high levels of an element are explained by the hormetic dose response, and they have opposite effects, stimulating and inhibiting plants responses (Calabrese and Blain 2009; Agathokleous et al. 2019b). In fact, plant growth and macronutrient status of some species are enhanced by low $\mathrm{Al}$ concentrations that have beneficial effects (Wang et al. 2015; Moreno-Alvarado et al. 2017). On the other hand, aluminum toxicity can inhibit absorption of water and nutrients, thereby serving as one of the most limiting factors for plants (Fujii et al. 2012; Guo et al. 2018). Limitations caused by aluminum can be directly related to reduced gas exchange and lower stomatal conductance and net photosynthesis, resulting in lower carbon assimilation and, in consequence, reduction in growth (Horst et al. 2010; Maire et al. 2015; Yang et al. 2015; Guo et al. 2018).

However, some species are well adapted to high Al availability in soils and are classified as Al-resistant species (Kochian et al. 2015). Some resistant species avoid Al through the release of organic compounds from the apex of the root to the soil (Kochian et al. 2015; Yang et al. 2015; Sade et al. 2016). Others tolerate high concentrations of aluminum by accumulating it in roots or aerial parts where concentrations have been recorded higher than $1000 \mathrm{mg} \mathrm{kg}^{-1}$ of aluminum complexed with organic acids (Haridasan 2008; Kochian et al. 2015; de Souza et al. 2017). In such cases, there are no modifications in nutrient uptake or in plant growth (Malta et al. 2016; de Souza et al. 2017).

The impacts of aluminum on farm crops and the strategies used by them are well studied (Kochian et al. 2004; Banhos et al. 2016a; Long et al. 2017). However, it is necessary to understand more about the effects of $\mathrm{Al}$ on native species (Haridasan 2008; Brunner and Sperisen 2013). Considering the $\mathrm{Al}$ content of Brazilian Cerrado soils, our research question was how do species cope with this metal during their period of initial establishment. Does H. impetiginosus display a typical hormetic response, being stimulated or inhibited by low and toxic $\mathrm{Al}$ doses? Does H. impetiginosus display any mechanism of resistance in its avoidance or tolerance of different Al concentrations? We analyzed growth, leaf nutrients, and photosynthetic characteristics of H. impetiginosus plants grown in four different aluminum concentrations, aiming to detect which strategy is used by this species.

\section{Materials and methods}

\section{Experimental design and plant material}

Seeds of H. impetiginosus were obtained from trees located at the Federal University of Lavras, Lavras-MG, Brazil $\left(21^{\circ} 13^{\prime} 40^{\prime \prime} \mathrm{S}\right.$ and $44^{\circ} 57^{\prime} 50^{\prime \prime} \mathrm{W}$ GRW). Seeds were sown in
Citropotes ${ }^{\circledR}$ containing river-washed sand. Four months after emergence plants were transferred to buckets containing $6 \mathrm{~L}$ of Hoagland and Arnon (1950) nutrient solution. Plants were acclimated in $1 / 4$ nutrient solution strength for 7 days, $1 / 2$ strength for 7 days, and full strength for 30 days. The nutrient solution was maintained by use of constant aeration and $\mathrm{pH}$ was adjusted to 5.5-6.5.

At the end of the acclimation period, four different aluminum concentrations were imposed. The nutrient solution of Hoagland and Arnon (1950) was modified and the concentrations of aluminum sulfate $\left(\mathrm{Al}_{2}\left(\mathrm{SO}_{4}\right)_{3} \cdot 14 \mathrm{H}_{2} \mathrm{O}\right)$ were 0 , 1,2 , and $4 \mathrm{mM} \mathrm{Al}$, based on previous study that estimated $4 \mathrm{mM}$ to be the highest concentration of aluminum found in Cerrado soil (Monteiro 2014). The soil pH was daily adjusted to $4.0 \pm 0.5$ in order to minimize the precipitation of aluminum and the solution was changed every 15 days.

Throughout the 40-day experiment, greenhouse temperature $\left({ }^{\circ} \mathrm{C}\right)$ and atmospheric relative humidity $(\mathrm{RH}-\%)$ were monitored by a thermohygrometer (Extech Instruments, model RHT10) located one meter above ground level. Vapor pressure deficit (VPD— $\mathrm{kPa}$ ) was calculated using temperature and relative humidity data (Jones 1992). The average temperature during our experimental period was $30^{\circ} \mathrm{C}$. Average RH was $74 \%$ and VPD was $2 \mathrm{kPa}$.

All measurements were recorded at the end of the experimental period. The experiment was arranged in a completely randomized design, with four $\mathrm{Al}$ concentrations $(0,1,2$, and $4 \mathrm{mM} \mathrm{Al}$ ) and five replications in each treatment. Each replication consisted of two plants, totalling 10 plants for each treatment.

\section{Growth analyses}

Shoot height $(\mathrm{cm})$, basal stem diameter $(\mathrm{mm})$, and number of leaves were measured, and then the plants were harvested and divided into the component categories leaves, stems, and roots, which were oven dried at $70{ }^{\circ} \mathrm{C}$ for $48 \mathrm{~h}$. The dry weight was used to determine the root to shoot ratio (R:S ratio).

\section{Leaf chlorophyll content and gas exchange}

Young, fully-expanded, and sun-lit leaves were used to measure leaf chlorophyll content and gas exchange characteristics. Total chlorophyll content was measured using a portable chlorophyll meter (atLEAF+). A mean was calculated from the measurements of eight of the ten leaves in each repetition. Gas exchange was evaluated between 9 and 11 a.m., using an infrared gas analyzer (IRGA-model LI-6400XT, Li-cor). The chamber was set with a photosynthetic photon flux density of $1000 \mu \mathrm{mol} \mathrm{m} \mathrm{m}^{-2} \mathrm{~s}^{-1}$. Leaf temperature was $30{ }^{\circ} \mathrm{C}$, relative humidity in the chamber was kept around $60 \%$, and leaf-to-air vapour pressure deficit 
(VPD) around $1.5 \mathrm{kPa}$. We determined net photosynthesis $\left(\mu \mathrm{mol} \mathrm{m}{ }^{-2} \mathrm{~s}^{-1}\right)$, stomatal conductance $\left(\mathrm{mol} \mathrm{m}{ }^{-2} \mathrm{~s}^{-1}\right)$, transpiration $\left.(\mathrm{mmol} \mathrm{m})^{-2} \mathrm{~s}^{-1}\right)$, and intercellular $\mathrm{CO}_{2}$ concentration $\left(\mu \mathrm{mol} \mathrm{mol}{ }^{-1}\right)$.

\section{Quantification of leaf mineral nutrients}

Young, fully-expanded, and sun-lit leaves were harvested, dried and ground to a powder in a Willey mill. Nitrogen (N) content was estimated using the Kjeldahl method from samples subjected to sulfuric digestion. Contents of other nutrients (Phosphorus-P; Potassium-K; Calcium- $\mathrm{Ca}$; Magnesium- $\mathrm{Mg}$; Sulfur-S; Copper- $\mathrm{Cu}$; Manganese$\mathrm{Mn}$; Zinc-Zn; Iron- $\mathrm{Fe}$; and $\mathrm{Al}$ ) were estimated using the curcumin colorimetric method after the samples were subjected to nitric perchloric digestion (except for Boron (B), which was digested by dry ashing). Nutrient contents were quantified by the colorimetric method of metavanadate $(\mathrm{P})$, flame photometry (Digimed NK-2002) (K), turbidimetric method of barium sulfate (S), atomic absorption spectrophotometry in an air-acetylene flame (Perkin Elmer, model AAnalyst 800$)(\mathrm{Ca}, \mathrm{Mg}, \mathrm{Cu}, \mathrm{Mn}, \mathrm{Zn}$, and $\mathrm{Fe}$ ) (reviewed by Malavolta et al. 1997). Al content was quantified using the aluminon method (Wang and Wood 1973). Results were expressed as percent of dry weight for $\mathrm{N}, \mathrm{P}, \mathrm{K}, \mathrm{Ca}, \mathrm{Mg}$, and $\mathrm{S}$; as $\mu \mathrm{g} \mathrm{g}^{-1}$ for $\mathrm{B}, \mathrm{Cu}, \mathrm{Mn}, \mathrm{Zn}$, and $\mathrm{Fe}$; and as $\mathrm{mM} \mathrm{g}^{-1}$ for $\mathrm{Al}$.

\section{Statistical analyses}

Data were analyzed by regression between the explanatory variable (aluminum concentration in the solution) and response variables. Among the response variables, Al leaf content (mM Al g $\left.{ }^{-1} \mathrm{DW}\right)$ was used as an explanatory variable in the regression analysis with the other response variables. All models obtained were analyzed using ANOVA $(p<0.05)$ and tested for normality of residuals (Shapiro-Wilk normality test), homoscedasticity (Breusch-Pagan test), and independence (Durbin-Watson test). For variables that did not meet one of the assumptions of normality, homoscedasticity or independence (growth and gas exchange characteristics; leaf chlorophyll content; $\mathrm{K}, \mathrm{Ca}, \mathrm{Mg}, \mathrm{S}, \mathrm{B}$, $\mathrm{Cu}, \mathrm{Mn}, \mathrm{Zn}$, and Fe content), a non-parametric analysis was performed using the Kruskal-Wallis test $(p<0.05)$ and means were compared using the post-hoc Nemenyi test. All analyses were performed in the $\mathrm{R}$ version 3.5.1@ (Team and R Development Core Team 2016).

\section{Results and discussion}

H. impetiginosus plants were able to transport $\mathrm{Al}$ to aerial parts, which caused impacts on nutritional status, photosynthetic activity, and plant growth. A linear increase was recorded for $\mathrm{Al}$ leaf content with increasing $\mathrm{Al}$ concentration in the nutrient solution. Highest leaf $\mathrm{Al}$ content of $0.88 \mathrm{mM}$ $\mathrm{Al} \mathrm{g}^{-1}$ DW was recorded for plants grown in $4 \mathrm{mM} \mathrm{Al}$ (Fig. 1). This indicated that this species does not have mechanisms to exclude or compartmentalize $\mathrm{Al}$ and the amount of $\mathrm{Al}$ may have caused competition among macronutrients.

In this context, gas exchange characteristics and $\mathrm{K}$ leaf content showed a typical hormetic dose response, in which stimulatory and inhibitory effects are provided by low and toxic doses, respectively (Agathokleous et al. 2019a; Calabrese et al. 2019). The low concentration of $1 \mathrm{mM}$ Al showed a stimulatory effect on net photosynthesis, stomatal conductance, and transpiration, with an increase of more than $50 \%$ in relation to the concentration of $0 \mathrm{mM} \mathrm{Al}$ (Fig. 2a-c). Aluminum supplementation may enhance photosynthetic activity, providing a higher supply of skeletons of carbon for the plant (Hajiboland et al. 2013). A higher value of $2.18 \%$ for $\mathrm{K}$ leaf content was also observed for the treatment $1 \mathrm{mM} \mathrm{Al}$ (Fig. 2d), possibly indicating that this nutrient plays a role in photosynthesis of plants under high $\mathrm{Al}$ conditions (Wang et al. 2015), by maintaining stomatal opening (Ridolfi and Garrec 2000).

Chlorophyll content was constant across the four treatments (Table 1) and there was a reduction in net photosynthesis as leaf $\mathrm{Al}$ content increased. The lowest value of $1.88 \mu \mathrm{mol} \mathrm{m}^{-2} \mathrm{~s}^{-1}$ was observed for plants grown in $4 \mathrm{mM}$ $\mathrm{Al}$ (Fig. 2a). The increase of $\mathrm{Al}$ content in leaves is closely related to nutritional deficiencies and lower photosynthetic activity (Ridolfi and Garrec 2000). Considering there is a strong relationship between photosynthetic rate and nutrient availability (Maire et al. 2015), one of the reasons for the observed negative effect on carbon assimilation is that

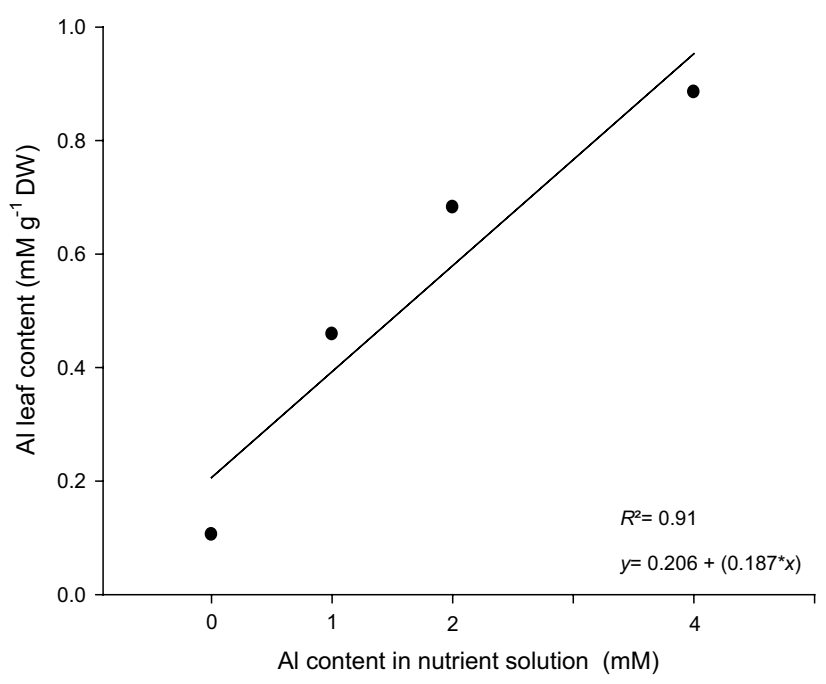

Fig. 1 Al leaf content of Handroanthus impetiginosus plants grown in four $\mathrm{Al}$ concentrations in nutrient solution. Symbols represent the mean of ten plants $(n=10)$ 

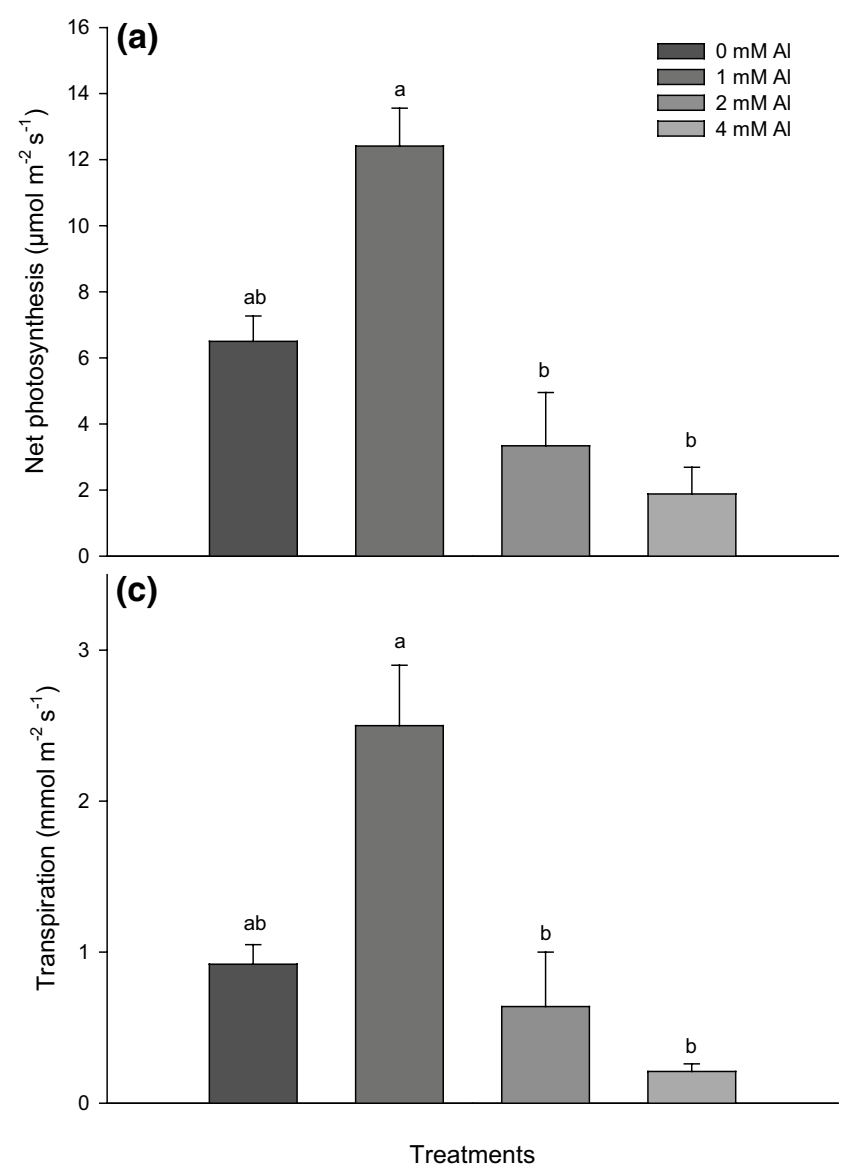

Fig. 2 Net photosynthesis, stomatal conductance, transpiration, and $\mathrm{K}$ leaf content of Handroanthus impetiginosus plants grown in four $\mathrm{Al}$ concentrations. Columns represent the mean $(\mathrm{n}=10)$ and bars are

Al might have affected nutrient uptake, as reported earlier (Lidon et al. 1999; Ribeiro et al. 2013; Muhammad et al. 2018). High aluminum concentration in soil leads to functional changes in roots, reducing the uptake of some cations due to competition with $\mathrm{Al}^{3+}$ (Sade et al. 2016) and inducing an $\mathrm{H}^{+}$efflux (Matsumoto 2000). Thus, the unbalanced $\mathrm{H}^{+}$transport alters membrane properties, rendering insufficient the transport of nutrients from roots to aerial parts (Mihailovic et al. 2008).

Most leaf nutrient contents were unaffected by $\mathrm{Al}$ treatment (Table 1). However, leaf concentrations of K, N, and $P$ showed remarkable reductions with increasing concentrations of Al, showing its toxic effects. Reduced K leaf content and decreased stomatal conductance and transpiration were recorded at lower values of $0.71 \%, 0.02 \mathrm{~mol} \mathrm{~m}^{-2} \mathrm{~s}^{-1}$,
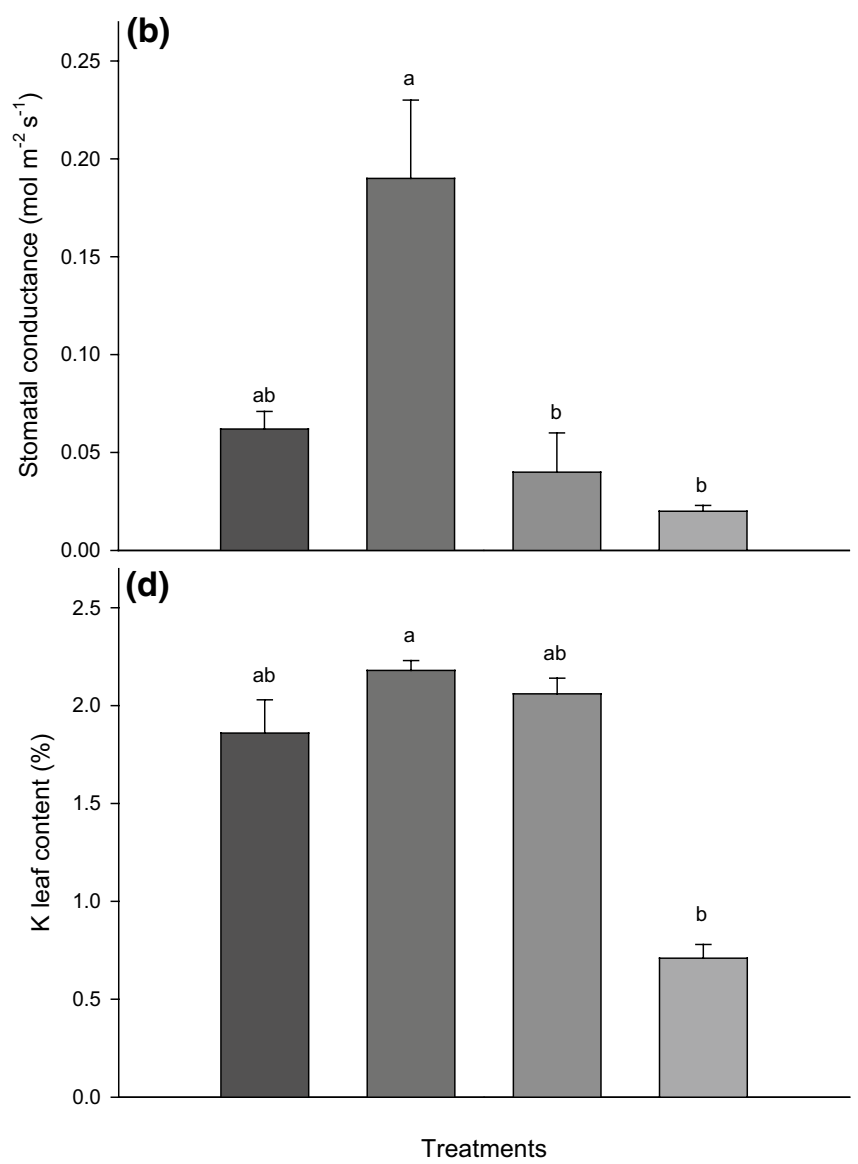

the standard error. Means followed by the same letters did not differ statistically according to the post-hoc Nemenyi test $(p<0.05)$

and $0.21 \mathrm{mmol} \mathrm{m}^{-2} \mathrm{~s}^{-1}$ for the treatment with $4 \mathrm{mM} \mathrm{Al}$. This was associated with decreased net photosynthesis (Fig. 2a-d). Modification in stomatal conductance and transpiration rates are commonly related to aluminium toxicity and the reduction of leaf $\mathrm{K}$ content might be responsible for stomatal closure in such conditions (Ridolfi and Garrec 2000; Mihailovic et al. 2008; Muhammad et al. 2018). A reduction in $\mathrm{K}$ in shoots was reported for a cacao-sensitive genotype grown in high aluminum concentrations (Ribeiro et al. 2013). Thus, it is possible that $H$. impetiginosus plants had a stomatal limitation, and consequently a reduction in carbon availability for photosynthesis. Other non-stomatal limitations affect photosynthesis of plants grown under $\mathrm{Al}$ stress (Yang et al. 2015). 
Although plants with leaf $\mathrm{Al}$ content of $0.46 \mathrm{mM} \mathrm{Al}$ $\mathrm{g}^{-1} \mathrm{DW}$ (treatment with $1 \mathrm{mM} \mathrm{Al}$ in the nutrient solution) showed a slight increase in leaf $\mathrm{N}$ content, there was a linear decrease of $\mathrm{N}$ and $\mathrm{P}$ leaf content as $\mathrm{Al}$ leaf content increased (Fig. 3). The lower values of 2.72 and $0.12 \%$ for $\mathrm{N}$ and $\mathrm{P}$, respectively, were recorded for the treatment with $4 \mathrm{mM} \mathrm{Al}$, which might explain the reduction in net photosynthesis by a biochemical limitation. These two nutrients are related to carboxylation enzymes assembly and operation (Rossatto et al. 2015). The amount of $\mathrm{N}$ used by the enzyme Ribulose-1,5-bisphosphate carboxylase/oxygenase (Rubisco) is high and can reach $27 \%$ of total leaf N (Evans 1989), while $\mathrm{P}$ is responsible for Rubisco activation and the regeneration of the Ribulose-1,5-bisphosphate (Pandey et al. 2015). Thus, the reduction of $\mathrm{N}$ and $\mathrm{P}$ leaf content might have led to lower content of Rubisco and turnover problems, causing the reduction in photosynthetic rates in H. impetiginosus plants grown in high $\mathrm{Al}$ concentration.

While our highest $\mathrm{Al}$ concentration resulted in toxic effects, our $0 \mathrm{mM} \mathrm{Al}$ trial reduced the gas exchange characteristics in comparison to the concentration of $1 \mathrm{mM} \mathrm{Al}$ (Fig. $2 \mathrm{a}-\mathrm{c}$ ). This suggests that $H$. impetiginosus plants needs low $\mathrm{Al}$ concentrations to stimulate photosynthetic activity. There was no difference for stem diameter, number of leaves, and $\mathrm{R}: \mathrm{S}$ ratio, among the four $\mathrm{Al}$ treatments (Table 1). For height, the lower carbon assimilation in the treatment with $4 \mathrm{mM} \mathrm{Al} \mathrm{may} \mathrm{have} \mathrm{reduced} \mathrm{the} \mathrm{availability} \mathrm{of} \mathrm{skeletons}$ of carbon for growth. We recorded about 50\% lower total heights for plants grown in $4 \mathrm{mM} \mathrm{Al}$ in comparison to the concentrations of 0 and $1 \mathrm{mM} \mathrm{Al} \mathrm{(Fig.} \mathrm{4).} \mathrm{Acid} \mathrm{soils} \mathrm{do} \mathrm{not}$ affect the growth of native species, unless there is a nutrient limitation (Haridasan 2008). Thus, the reduction in $\mathrm{N}$, $\mathrm{P}$, and $\mathrm{K}$ content could represent a restriction of metabolite resources that was responsible for reduced shoot growth. Shoot growth reduction was reported for Styrax camporum, indicating that $\mathrm{Al}$ may negatively affect the shoot apical meristem (Banhos et al. 2016b).

The increase in $\mathrm{Al}$ content led to nutritional imbalance which was responsible for the reduction in gas exchange and shoot growth. Regardless of its wide distribution in Cerrado landscapes, our results suggest that $H$. impetiginosus suffered constraints caused by Al concentrations similar to those observed in field conditions, showing that it is a non-resistant species. We hypothesize that the occurrence of this species is restricted to sites where $\mathrm{Al}$ concentrations are lower than at other sites. This is supported by the stimulatory effects of the treatment with $1 \mathrm{mM} \mathrm{Al}$ in photosynthetic activity, $\mathrm{K}$, and $\mathrm{N}$ leaf content. Further studies are needed to identify physiological mechanisms displayed by H. impetiginosus plants grown under low Al concentrations and to understand responses of this species in conditions of increasing $\mathrm{Al}$ content in the soil due to climate change. 

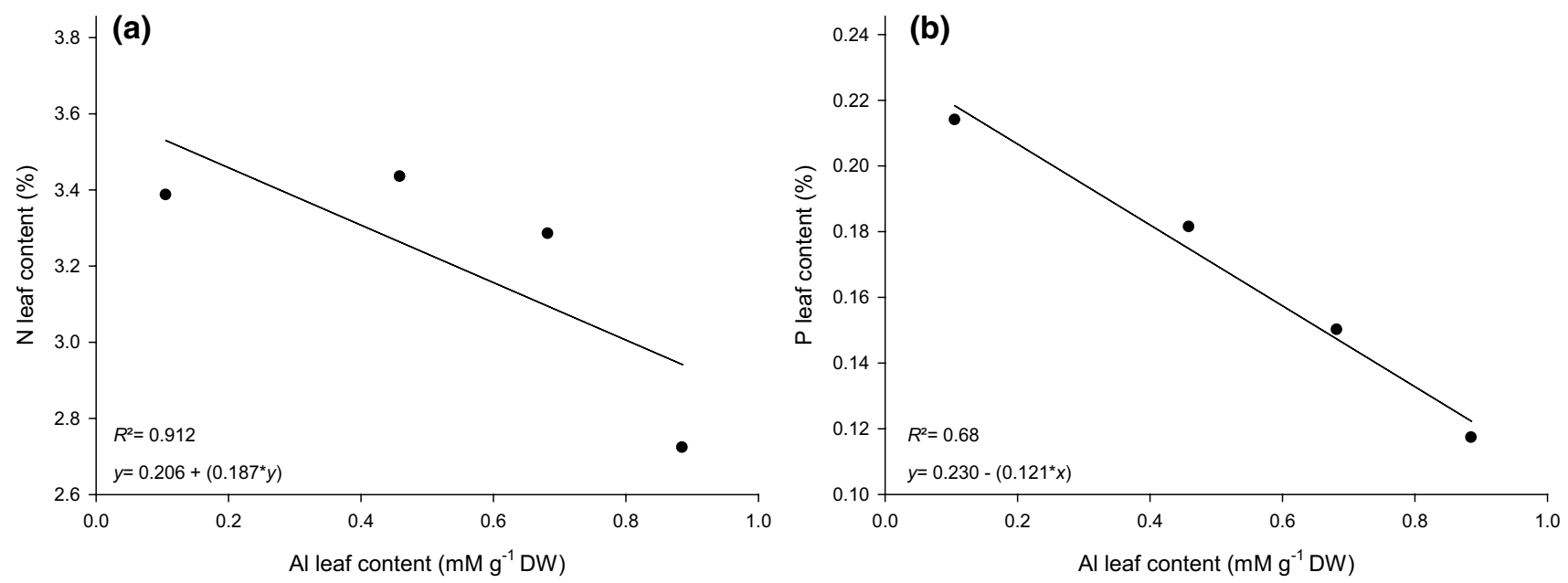

Fig. $3 \mathrm{~N}$ and $\mathrm{P}$ leaf content of Handroanthus impetiginosus plants grown in four different $\mathrm{Al}$ leaf concentrations. Symbols represent the mean of ten plants $(n=10)$

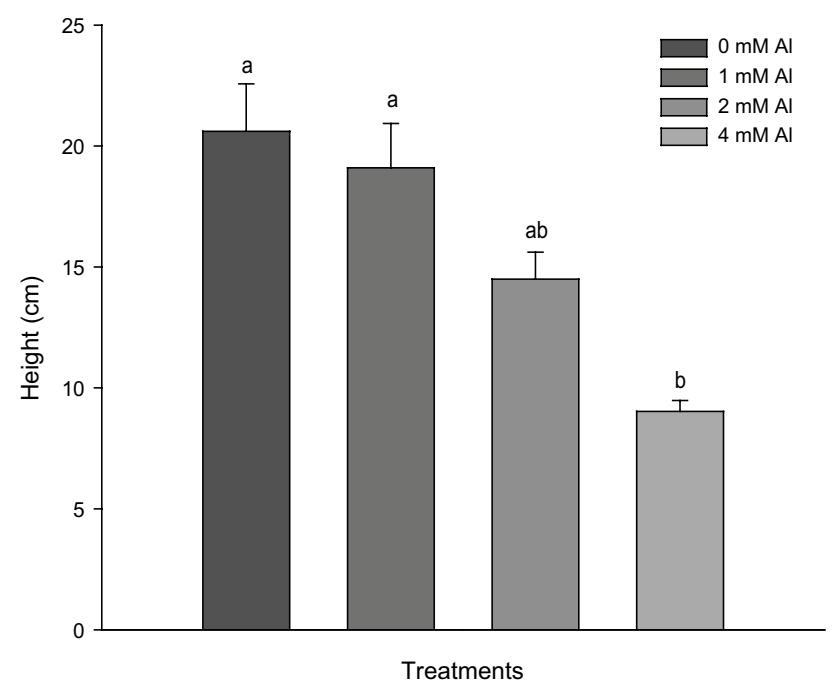

Fig. 4 Height of Handroanthus impetiginosus plants grown in four different $\mathrm{Al}$ concentrations. Columns represent the mean $(\mathrm{n}=10)$ and bars the standard error. Means followed by the same letters do not differ statistically according to the post-hoc Nemenyi test $(p<0.05)$

\section{Conclusions}

During the initial establishment, $H$. impetiginosus plants showed a hormetic response. Low Al concentration stimulated photosynthetic responses and maintained $\mathrm{K}$ and $\mathrm{N}$ leaf content, showing the beneficial effects of this metal.
However, higher $\mathrm{Al}$ concentrations, e.g., $4 \mathrm{mM} \mathrm{Al}$, led to $\mathrm{Al}$ accumulation in leaves, a condition in which there were nutritional disorders and reductions of gas exchange and growth. Thus, when grown in soils with high $\mathrm{Al}$ content, $H$. impetiginosus plants suffered with toxic effects and did not show any mechanism of Al-resistance.

Acknowledgements This study was financed in part by the Coordenação de Aperfeiçoamento de Pessoal de Nível Superior-Brazil (CAPES)-Financial Code 001 and the Conselho Nacional de Desenvolvimento Científico e Tecnológico-Brazil (CNPq) by providing scholarship for the authors.

Open Access This article is distributed under the terms of the Creative Commons Attribution 4.0 International License (http://creativeco mmons.org/licenses/by/4.0/), which permits unrestricted use, distribution, and reproduction in any medium, provided you give appropriate credit to the original author(s) and the source, provide a link to the Creative Commons license, and indicate if changes were made.

\section{References}

Agathokleous E, Kitao M, Calabrese EJ (2019a) Hormesis: a compelling platform for sophisticated plant science. Trends Plant Sci 24:318-327

Agathokleous E, Kitao M, Harayama H, Calabrese EJ (2019b) Temperature-induced hormesis in plants. J For Res 30:13-20

Banhos OFAA, Brenda BM, da Veiga EB et al (2016a) Aluminuminduced decrease in $\mathrm{CO}_{2}$ assimilation in "Rangpur" lime is associated with low stomatal conductance rather than low photochemical performances. Sci Hortic (Amsterdam) 205:133-140 
Banhos OFAA, de Souza MC, Habermann G (2016b) High aluminum availability may affect Styrax camporum, an Al nonaccumulating species from the Brazilian savanna. Theor Exp Plant Physiol 28:321-332

Bojórquez-Quintal E, Escalante-Magaña C, Echevarría-Machado I, Martínez-Estévez M (2017) Aluminum, a friend or foe of higher plants in acid soils. Front Plant Sci 8:1-18

Brunner I, Sperisen C (2013) Aluminum exclusion and aluminum tolerance in woody plants. Front Plant Sci 4:1-12

Calabrese EJ, Blain RB (2009) Hormesis and plant biology. Environ Pollut 157:42-48

Calabrese EJ, Agathokleous E, Kozumbo WJ et al (2019) Estimating the range of the maximum hormetic stimulatory response. Environ Res 170:337-343

de Souza MC, Habermann G, do Amaral CL, Rosa AL, Pinheiro MHO, da Costa FB (2017) Vochysia tucanorum Mart.: an aluminum-accumulating species evidencing calcifuge behavior. Plant Soil 419:377-389

Evans JR (1989) Photosynthesis and nitrogen relationships in leaves of $\mathrm{C}_{3}$ plants. Oecologia 78:9-19. https://doi.org/10.1007/BF003 77192

Fageria NK (2001) Efeito da calagem na produção de arroz, feijão, milho e soja em solo de cerrado. Pesqui Agropecu Bras 36:1419-1424

Fujii M, Yokosho K, Yamaji N, Saisho D, Yamane M, Takahashi H, Sato K, Nakazono M, Ma JF (2012) Acquisition of aluminium tolerance by modification of a single gene in barley. Nat Commun 3:713-719

Guo P, Qi YP, Cai YT, Yang TY, Yang LT, Huang ZR, Chen LS (2018) Aluminum effects on photosynthesis, reactive oxygen species and methylglyoxal detoxification in two Citrus species differing in aluminum tolerance. Tree Physiol 38:1548-1565

Hajiboland R, Bahrami Rad S, Barceló J, Poschenrieder C (2013) Mechanisms of aluminum-induced growth stimulation in tea (Camellia sinensis). J Plant Nutr Soil Sci 176:616-625

Haridasan M (2008) Nutritional adaptations of native plants of the cerrado biome in acid soils. Braz J Plant Physiol 20:183-195

Hoagland DR, Arnon DI (1950) The water culture method for growing plants without soils. California Agricultural Experimental Station, Berkeley, p 347

Horst WJ, Wang Y, Eticha D (2010) The role of the root apoplast in aluminium-induced inhibition of root elongation and in aluminium resistance of plants: a review. Ann Bot 106:185-197

Jones HG (1992) Plants and microclimate: a quantitative approach to environmental plant physiology, 2nd edn. Cambridge University Press, Cambridge, $\mathrm{p} 85$

Kochian LV, Hoekenga OA, Piñeros MA (2004) How do crop plants tolerate acid soils? Mechanisms of aluminum tolerance and phosphorous efficiency. Annu Rev Plant Biol 55:459-493. https://doi. org/10.1146/annurev.arplant.55.031903.141655

Kochian LV, Piñeros MA, Liu J, Magalhaes JV (2015) Plant adaptation to acid soils: the molecular basis for crop aluminum resistance. Annu Rev Plant Biol 66:571-598

Lidon FC, Barreiro MG, Ramalho JC, Lauriano JA (1999) Effects of aluminum toxicity on nutrient accumulation in maize shoots: implications on photosynthesis. J Plant Nutr 22:397-416

Long A, Zhang J, Yang L-T, Ye X, Lai N-W, Tan L-L, Lin D, Chen L-S (2017) Effects of low pH on photosynthesis, related physiological parameters, and nutrient profiles of Citrus. Front Plant Sci 8:1-22

Lorenzi H (2008) Árvores brasileiras: manual de identificação e cultivo de plantas arbóreas nativas do Brasil, 5th edn. Instituto Plantarum, Nova Odessa, p 384

Maire V, Wright IJ, Prentice IC, Batjes NH, Bhaskar R, van Bodegom PM, Cornwell WK, Ellsworth D, Niinemets U, Ordonez A, Reich PB, Santiago LS (2015) Global effects of soil and climate on leaf photosynthetic traits and rates. Glob Ecol Biogeogr 24:706-717
Malavolta E, Vitti GC, Oliveira SA (1997) Avaliação do estado nutricional das plantas: princípios e aplicações, 2nd edn. Potafos, Piracicaba, p 319

Malta PG, Arcanjo-Silva S, Ribeiro C, Campos NV, Azevedo AA (2016) Rudgea viburnoides (Rubiaceae) overcomes the low soil fertility of the Brazilian Cerrado and hyperaccumulates aluminum in cell walls and chloroplasts. Plant Soil 408:369-384

Matsumoto H (2000) Cell biology of aluminum toxicity and tolerance in higher plants. Int Rev Citol 200:1-46

Miatto RC, Wright IJ, Batalha MA (2016) Relationships between soil nutrient status and nutrient-related leaf traits in Brazilian cerrado and seasonal forest communities. Plant Soil 404:13-33

Mihailovic N, Drazic G, Vucinic Z (2008) Effects of aluminium on photosynthetic performance in Al-sensitive and Al-tolerant maize inbred lines. Photosynthetica 46:476-480

Monteiro VFC 2014 Crescimento radial e resposta ecofisiológica de Vochysia thyrsoidea (Pohl.) às condições ambientais do cerrado rupestre. Dissertation, Universidade Federal de Lavras, Lavras, p 84

Moreno-Alvarado M, García-Morales S, Trejo-Téllez LI, Hidalgo-Contreras JV, Gómez-Merino FC (2017) Aluminum enhances growth and sugar concentration, alters macronutrient status and regulates the expression of NAC transcription factors in rice. Front Plant Sci 8:1-16

Muhammad N, Zvobgo G, Guo-ping Z (2018) A review: the beneficial effect of aluminum on plant growth in acid soil and the possible mechanisms. J Integr Agric 17:60345-60347

Pandey R, Zinta G, AbdElgawad H, Ahmad A, Jain V, Janssens IA (2015) Physiological and molecular alterations in plants exposed to high $\left[\mathrm{CO}_{2}\right]$ under phosphorus stress. Biotechnol Adv 33:303-316

Ribeiro MAQ, de Almeida AAF, Mielke MS, Gomes FP, Pires MV, Baligar VC (2013) Aluminum effects on growth, photosynthesis, and mineral nutrition of cacao genotypes. J Plant Nutr 36:1161-1179

Ridolfi M, Garrec J-P (2000) Consequences of an excess Al and a deficiency in $\mathrm{Ca}$ and $\mathrm{Mg}$ for stomatal functioning and net carbon assimilation of beech leaves. Ann For Sci 57:209-218

Rossatto DR, Carvalho FA, Haridasan M (2015) Soil and leaf nutrient content of tree species support deciduous forests on limestone outcrops as a eutrophic ecosystem. Acta Bot Bras 29:231-238

Sade H, Meriga B, Surapu V, Gadi J, Sunita MSL, Suravajhala P, Kishor PBK (2016) Toxicity and tolerance of aluminum in plants: tailoring plants to suit to acid soils. Biometals 29:187-210

Salomão AN, Camilo J (2016) Handroanthus impetiginosus. In: Vieira RF, Camillo J, Coradin L (eds) Espécies nativas da flora brasileira de valor econômico atual ou potencial. Ministério do Meio Ambiente, Brasília, pp 801-812

Scolforo JRS (2008) Características e produção das fisionomias do Cerrado em Minas Gerais. In: Faleiro FG, Farias Neto AL (eds) Savanas: desafios e estratégias para o equilíbrio entre sociedade, agronegócio e recursos naturais. Embrapa Cerrado, Planaltina, pp 505-610

Siqueira Neto M, De Cássia Piccolo M, Scopel E, Da Costa Júnior C, Cerri CC, Bernoux EM (2009) Carbono total e atributos químicos com diferentes usos do solo no cerrado. Acta Sci Agron 31:709-717

Team RDC, R Development Core Team R (2016) R: a language and environment for statistical computing. R Found Stat Comput.

Wang C, Wood FA (1973) A modified aluminon reagent for the determination of aluminum after $\mathrm{HNO}_{3}-\mathrm{H}_{2} \mathrm{SO}_{4}$ digestion. Can J Soil Sci 53:237-239

Wang L, Fan XW, Pan JL, Huang ZB, Li YZ (2015) Physiological characterization of maize tolerance to low dose of aluminum, highlighted by promoted leaf growth. Planta 242:1391-1403 
Yang M, Tan L, Xu Y, Zhao Y, Cheng F, Ye S, Jiang W (2015) Effect of low $\mathrm{pH}$ and aluminum toxicity on the photosynthetic characteristics of different fast-growing Eucalyptus vegetatively propagated clones. PLoS ONE 10:1-15
Publisher's Note Springer Nature remains neutral with regard to jurisdictional claims in published maps and institutional affiliations. 